\title{
DIRECTIONS AND DYNAMICS OF FLOW AND TRANSPORT OF CONTAMINANTS FROM THE LANDFILL NEAR SEŽANA (SW SLOVENIA)
}

\author{
SMERI IN DINAMIKA ODTEKANJA VODE IN PRENOSA \\ KONTAMINANTOV Z ODLAGALIŠČA ODPADKOV PRI SEŽANI \\ (JZ SLOVENIJA)
}

\author{
Janja KOGOVŠEK ${ }^{1} \&$ Metka PETRIČ ${ }^{1}$
}

\begin{abstract}
UDC 556.3:504.054(497.4)

$556.34 .04(497.4)$

Janja Kogovšek \& Metka Petrič: Directions and dynamics of flow and transport of contaminants from the landfill near Sežana (SW Slovenia)

The characteristics of flow from the landfill near Sežana in the area of Kras were studied by the use of tracer test. In well permeable fissure on the karren surface near the landfill the fluorescent dye uranine was injected in order to study the directions and velocities of its flow through the karst aquifer. Monitoring of tracer concentrations in the period of one year and a half enabled us to make some conclusions about the dynamics of groundwater flow in the directions towards the Timava, Brojnica and Sardoč springs. Detailed observations were organised also at the Klariči pumping station, which is the main source of drinking water for the Kras region. Increased concentrations of tracer were measured only during extremely high waters. Different explanations are possible, but we can not exclude the possibility of a weak, not permanent underground water connection with the landfill. Calculation of the amount of recovered tracer confirmed the main flow direction towards the Timava springs (recovery rate 93\%) and a secondary direction with lower flow velocity towards the Brojnica and Sardoč springs. Outflow through the Klariči pumping is estimated to only $0.003 \%$ of injected uranine.
\end{abstract}

Key words: tracer test, landfill, Sežana, Kras, Slovenia.
Izvleček

UDK 556.3:504.054(497.4)

$556.34 .04(497.4)$

Janja Kogovšek \& Metka Petrič: Smeri in dinamika odtekanja vode in prenosa kontaminantov $z$ odlagališča odpadkov pri Sežani (JZ Slovenija)

S sledilnim poskusom smo raziskali značilnosti odtekanja vode z odlagališča komunalnih odpadkov pri Sežani na območju Krasa. V dobro prepustno razpoko na škrapljišču ob odlagališču smo injicirali uranin in ugotavljali smeri in hitrosti njegovega pretakanja skozi kraški vodonosnik. Spremljanje pojavljanja sledila $\mathrm{v}$ obdobju enega leta in pol je pokazalo dinamiko pretakanja v smeri izvirov Timave, Brojnice in Sardoča. Podrobno smo opazovali tudi črpališče Klariči, ki predstavlja glavni vir pitne vode za območje Krasa. Za ugotovljeno povečanje koncentracije sledila le ob zelo visokih vodostajih so možne različne razlage, ne izključujemo pa možnosti obstoja slabe in le občasne povezave $\mathrm{z}$ odlagališčem. Izračun povrnjenega sledila je pokazal predvsem odtekanje proti izvirom Timave (delež povrnjenega sledila $93 \%$ ), majhen del sledila se je ob počasnejšem pretakanju pojavil tudi v Brojnici in Sardoču. Na črpališču Klariči naj bi izteklo le 0,003 \% injiciranega uranina.

Ključne besede: sledilni poskus, odlagališče odpadkov, Sežana, Kras, Slovenija.

\section{INTRODUCTION}

Karstological and hydrogeological researches have a long tradition in the area of Classical karst or Kras (Fig. 1). Underground water connections between the sinking streams from non-karstic surroundings and the springs in the Trieste bay were proved by several tracer tests. Most of the studies were focused on the underground flow of the Reka river between the ponor in the Škocjanske jame and the Timava springs. Main directions and high velocities of flow through well permeable karst channels were proved. On the other hand, different researches indicated

${ }^{1}$ Karst Research Institute ZRC SAZU, Titov trg 2, SI-6230 Postojna, Slovenija, e-mail: kogovsek@zrc-sazu.si, petric@zrc-sazu.si Received/Prejeto: 13.09.2007 


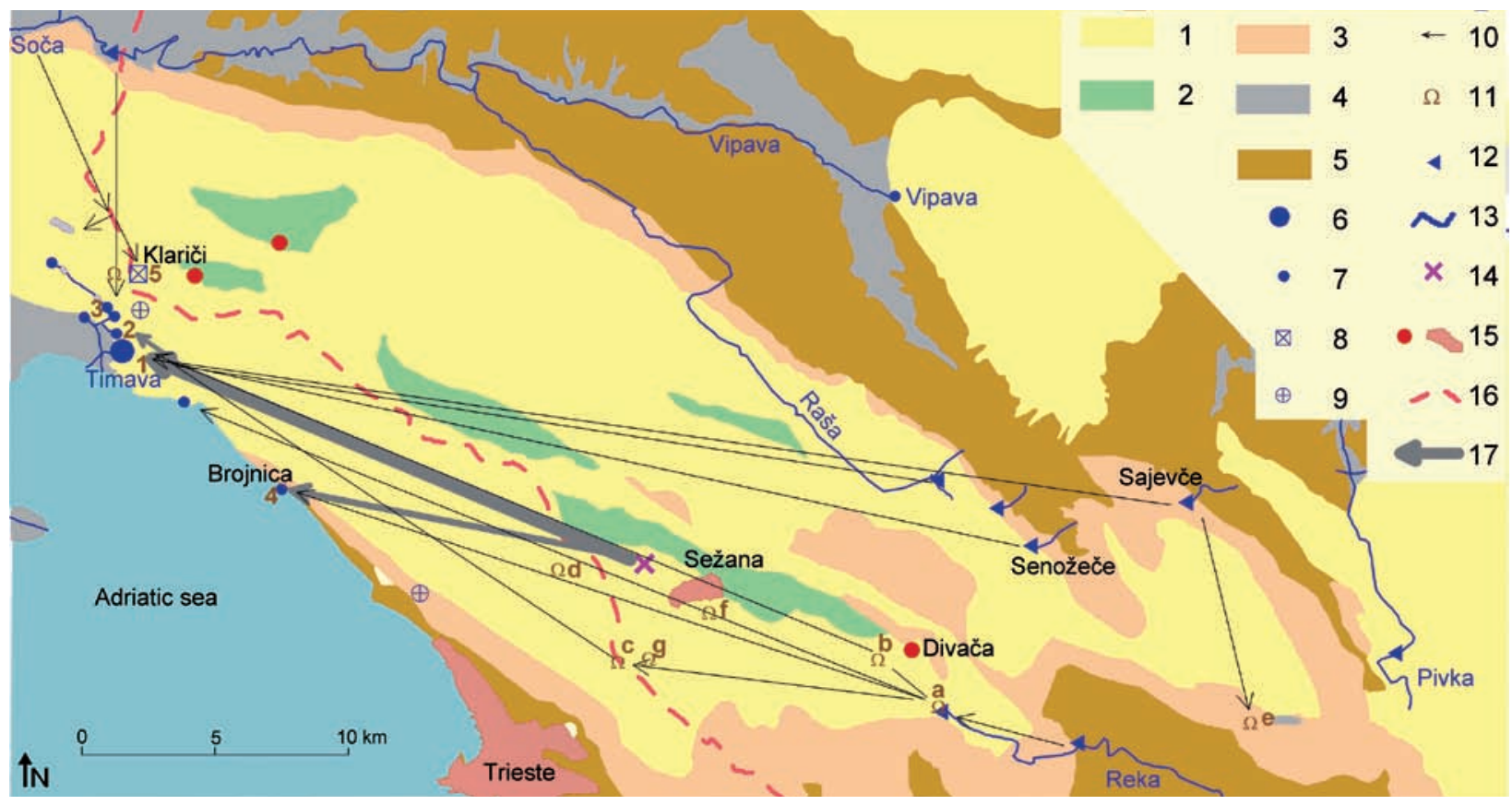

Fig. 1: Hydrogeological map of Kras with the results of tracer tests (Legend: 1. Well permeable Cretaceous limestone, 2. Slightly less permeable Cretaceous dolomite, 3. Well permeable Tertiary limestone and dolomite, 4. Porous aquifer, 5. Very low permeable Eocene flysch, 6. Timava spring, 7. Spring, 8. Pumping station, 9. Piezometer, 10. Underground water connection, proved by previous tracer tests, 11. Karst cave (a. Škocjanske jame, b. Kačna jama, c. Labodnica, d. Lazzaro Jerko, e. Gabranca, f. Jama 1 v Kanjaducah, g. Brezno $v$ Stršinkni dolini), 12. Sinking stream, 13. Surface flow, 14. Landfill, 15. Settlement, 16. State border, 17. Underground water connection, proved by tracer test in 2005).

Main sampling points (numbers in brown colour): 1. Timava spring, 2. Sardoč spring, 3. Moščenice-N spring, 4. Brojnica spring, 5. Klariči pumping station.

Sl. 1: Hidrogeološka karta Krasa z rezultati sledilnih poskusov (Legenda: 1. dobro prepusten kredni apnenec, 2. nekoliko slabše prepusten kredni dolomit, 3. dobro prepustni terciarni apnenci in dolomiti, 4. medzrnski vodonosnik, 5. zelo slabo prepusten eocenski fliš, 6. izvir Timave, 7. izvir, 8. črpališče, 9. piezometer, 10. s starejšim sledilnim poskusom dokazana podzemna vodna zveza, 11. kraška jama (a. Škocjanske jame, b. Kačna jama, c. Labodnica, d. Lazzaro Jerko, e. Gabranca, f. Jama 1 v Kanjaducah, g. Brezno v Stršinkni dolini), 12. ponikalnica, 13. površinski tok, 14. odlagališče Sežana, 15. naselje, 16. državna meja, 17. pri sledenju 2005 dokazana podzemna vodna zveza).

Glavne točke zajemanja vzorcev (številke v rjavi barvi): 1. izvir Timave, 2. izvir Sardoč, 3. izvir Moščenice-N, 4. izvir Brojnica, 5. črpališče Klariči.

an important share of primary recharge with diffuse infiltration of precipitation through the karst surface. The thickness of the vadose zone on Kras can reach even more than $300 \mathrm{~m}$, therefore this zone has a significant influence on the characteristics of water flow and transport of substances towards the karst springs.

These general characteristics of the area were considered in the study of directions and dynamics of flow and transport of contaminants from the landfill near Sežana. The landfill is situated on the Kras area approximately $2 \mathrm{~km}$ north-western from the town of Sežana at the altitude of around $360 \mathrm{~m}$ (Fig. 1). It was opened in 1971 and at present the total amount of deposited waste is nearly $200.000 \mathrm{t}$. Yearly around $10.000 \mathrm{t}$ of non-hazardous waste from four municipalities with altogether 22.000 inhabitants is deposited (Komunalno stanovan- jsko podjetje 2005). According to the new Slovene legislation no landfills on karst are allowed, therefore for the Sežana landfill closing as well as its further maintenance and protection is foreseen. But even before, it is necessary to set the monitoring system, which also includes measurements of parameters of groundwater pollution with harmful substances. Preparation of the monitoring plan is based on adequate hydrogeological researches, because it is necessary to know the characteristics of flow from the landfill in order to choose representative monitoring points and prepare efficient monitoring plan.

For this purpose one of the most effective methods on karst are tracer tests. Several were carried out on the Kras area in the past, but in all of them the tracers were injected into a sinking stream or into a water flow in a cave. This means direct input into the primary drainage 
channels and fast flow towards karst springs, therefore obtained results are not representative for the assessment of the characteristics of diffuse infiltration and flow through the vadose zone. Many researches, including several carried out on Slovene karst (Kogovšek \& Petrič 2006, Trček 2006), proved an important influence of epikarst and vadose zone on the characteristics of water flow and transport of substances through karst aquifers. Therefore to define the characteristics of flow of leachates from the Sežana landfill we decided to carry out a new tracer test with the injection of tracer into a well permeable fissure at the karren surface near the landfill. Our main questions were: in which direction and how fast infiltrated precipitation water from the landfill flows, how fast is the transport of harmful substances washed out of the waste, and in which springs or water caves the appearance of these substances can be expected? Long-term simultaneous measurements of precipitation, discharges and tracer concentrations enabled assessment of influences of precipitation with various intensities and durations on the appearance of tracer in the springs and consequently of the influence of the vadose zone on groundwater flow.

\section{CHARACTERISTICS OF THE STUDY AREA}

\section{HYDROGEOLOGICAL CHARACTERISTICS}

The central part of Kras (Fig. 1) is built of well karstified and well permeable Cretaceous limestone and partly dolomite in the thickness of more than $1000 \mathrm{~m}$ (Kranjc 1997). Dolomite layers are slightly less permeable and may play a role of a relative isolator. To the north, south and east the Cretaceous carbonate rocks pass into bedded and tabular limestone of Tertiary age, which is also fissured and karstified. The carbonate massif is surrounded with very low permeable Eocene flysch which acts as an important hydrogeological barrier. There where flysch is interrupted numerous springs in the Trieste bay of the Adriatic sea appear. In the north-western part the Kras aquifer is in contact with the porous aquifer of alluvial sediments deposited along the Soča and Vipava rivers. The massif of Kras is dissected with numerous faults also. Directions E-W prevail, but they can turn into directions NW-SE and NE-SW. Along the latter the Timava springs and some karst caves with permanent water flow are situated.

It is a typical characteristic of Kras that there are practically no superficial streams. Due to a high permeability of carbonate rocks and consequently almost immediate infiltration of rainwater the share of surface flow is negligible. On the other hand, a dense network of surface drainage is developed on surrounding areas with lower permeability. On the contact with the karst aquifer these streams sink underground and flow through the karst system towards the springs in the Trieste bay. The biggest among them is the Timava spring (Fig. 2) with discharges from $9.1 \mathrm{~m}^{3} / \mathrm{s}$ to $127 \mathrm{~m}^{3} / \mathrm{s}$, and mean discharge $30.2 \mathrm{~m}^{3} / \mathrm{s}$ in the period 1972-1983 (Civita et al. 1995). The Timava spring has three main branches which are usually marked with numbers 1, 2 and 3. In some previous researches their physico-chemical properties were compared in more details (Reisenhofer et al. 1998). Although some

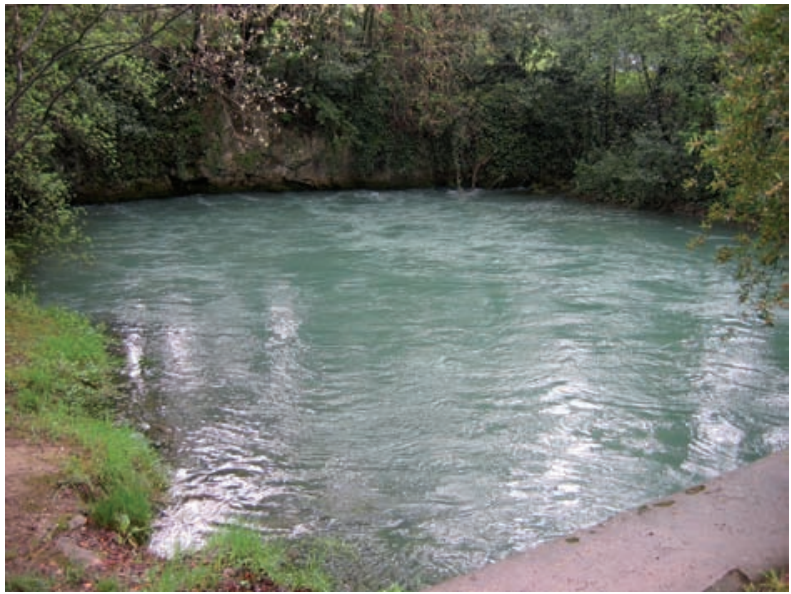

Fig. 2: The Timava spring.

Sl. 2: Izvir Timave.

differences were observed, they show similar general characteristics. Several smaller springs are located further inland at the altitudes from 0.4 to $12 \mathrm{~m}$ above the sea level. Especially interesting are submarine springs along the coast between Timava springs and Trieste. The most important is the one near the village Nabrežina (Aurisina), which is called Brojnica and has been captured for the water supply from 1857 until 1977.

The karst aquifer of Kras, which is drained through described springs, is recharged mainly by primary infiltration of precipitation through well karstified surface. Average yearly precipitation on Kras varies from 1400 to $1650 \mathrm{~mm}$, and average yearly evapotranspiration from 700 to $750 \mathrm{~mm}$ (Kolbezen \& Pristov 1998). So the effective precipitation, which actually recharges the aquifer, amounts to 700-900 $\mathrm{mm}$. With some numerical estimations the share of such primary infiltration in the total water balance was assessed to approximately $65 \%$ (Civita et al. 1995). 
Additionally, the Kras aquifer is recharged by sinking streams from the surrounding area. The most important is the contribution of the Reka river which sinks into the Škocjanske jame at the south-eastern border of Kras. As it was proved by several tracer tests, which are described in the next subchapter, it reappears again in the springs of the Trieste bay. In the period 1961-1990 the lowest measured discharge of the Reka river at the gauging station Cerkvenikov mlin was $0.18 \mathrm{~m}^{3} / \mathrm{s}$ and the mean discharge $8.26 \mathrm{~m}^{3} / \mathrm{s}$ (Kolbezen \& Pristov 1998). In the time of extremely high waters its discharge can reach up to more than $300 \mathrm{~m}^{3} / \mathrm{s}$. Less important is the contribution of the inflows from the sand and gravel sediments in the Soča and Vipava river basins, as well as from the ponors of the Raša river, Sajevče brook and sinking streams near Dolenja vas and Senožeče (Fig. 1).

In the karst aquifer between the sinking points of the surface streams and the springs, the underground water is accessible in some deep caves and boreholes. The depth to the water table is considerable. On the eastern part of the aquifer the water is found during low water level in the Škocjanske jame at $210 \mathrm{~m}$ a.s.l. The water table lowers towards the Kačna Jama to 156 m, in the cave of Labodnica (Trebiciano Abyss) the water is found at 12 $\mathrm{m}$, in the boreholes near Klariči at $2 \mathrm{~m}$, while in the immediate vicinity of the Timava springs at $0.4 \mathrm{~m}$ above sea level (Civita et al. 1995). A fast increase of this level is controlled by heavy rainfall and at high waters the system is extremely filled up. Water table in the caves rises by 30 $\mathrm{m}$ in the western part and by more than hundred meters at east. Access to the underground water flow is possible in some other deep caves also. On the Slovene side of the border such caves are Jama $1 \mathrm{v}$ Kanjaducah and Brezno $v$ Stršinkni dolini. In several caves the oscillations of water table are regularly monitored (Cucchi \& Zini 2002, Gabrovšek \& Peric 2006).

In the pumping station near Klariči karst water has been pumped out for the water supply of 5 communes in the Kras region since 1983. The exploitation wells are located at the altitude $16 \mathrm{~m}$ in the bottom of the karst doline approximately $4 \mathrm{~km}$ northern from the springs of Timava. At the moment 3 wells with the diameter of $0.6 \mathrm{~m}$ and the depth of $70 \mathrm{~m}$ are active. The water table is about $2 \mathrm{~m}$ above sea level. Up to $250 \mathrm{l} / \mathrm{s}$ of water can be pumped at present from all three wells. In the first stage the water is pumped up to the water reservoir Sela na Krasu at the altitude $275 \mathrm{~m}$, where also the water treatment station is located. From this reservoir water is distributed to users through an extended water supply system which covers practically the whole Kras area.

\section{PREVIOUS TRACER TESTS}

First tracer tests in the Kras area were carried out at the beginning of $20^{\text {th }}$ century, and several tests with artificial tracers were performed in the following years. Obtained results enable better understanding of the characteristics and directions of groundwater flow at different hydrological conditions (Fig. 1 and Tab. 1).

\begin{tabular}{|c|c|c|c|c|c|}
\hline Injection point & $\begin{array}{l}\text { Date of } \\
\text { injection }\end{array}$ & Tracer & Proved connection & $\begin{array}{l}\text { Appar. flow } \\
\text { velocity }\end{array}$ & Reference \\
\hline Reka river (Škocjanske jame) & 23.12 .1907 & $\mathrm{LiCl}$ & $\begin{array}{l}\text { Timava spring } \\
\text { Brojnica spring }\end{array}$ & $\begin{array}{l}162 \mathrm{~m} / \mathrm{h} \\
128 \mathrm{~m} / \mathrm{h}\end{array}$ & Timeus 1928 \\
\hline Reka river (Škocjanske jame) & 28.1.1913 & Uranine & Labodnica Cave & $97 \mathrm{~m} / \mathrm{h}$ & Timeus 1928 \\
\hline Reka river (Škocjanske jame) & 3.7.1962 & Uranine, Tritium & $\begin{array}{l}\text { Labodnica Cave } \\
\text { Brojnica spring } \\
\text { Timava spring } \\
\text { Boljunec spring }\end{array}$ & $\begin{array}{l}200 \mathrm{~m} / \mathrm{h} \\
50 \mathrm{~m} / \mathrm{h} \\
86 \mathrm{~m} / \mathrm{h} \\
104 \mathrm{~m} / \mathrm{h}\end{array}$ & Mosetti 1965 \\
\hline Labodnica Cave & 1908 & Uranine & Timava spring & $100 \mathrm{~m} / \mathrm{h}$ & Timeus 1928 \\
\hline Vipava river (near Vrtoče) & 20.5.1910 & $\begin{array}{l}\mathrm{LiCl} \\
\mathrm{SrCl}_{2}\end{array}$ & $\begin{array}{l}\text { Doberdob Lake } \\
\text { Timava spring }\end{array}$ & $104 \mathrm{~m} / \mathrm{h}$ & Timeus 1928 \\
\hline Sajevče brook & 29.6.1987 & Uranine & Timava spring & $24 \mathrm{~m} / \mathrm{h}$ & Habič 1989 \\
\hline Senožeče brook & 29.6.1987 & Phages & $\begin{array}{l}\text { Timava spring } \\
\text { Sardoč spring } \\
\text { Moščenice spring }\end{array}$ & $\begin{array}{l}86 \mathrm{~m} / \mathrm{h} \\
? \\
65 \mathrm{~m} / \mathrm{h}\end{array}$ & Habič 1989 \\
\hline Raša river (near Dolenja vas) & 29.6.1987 & Rhodamine & $\begin{array}{l}\text { Timava spring } \\
\text { Sardoč spring } \\
\text { Moščenice spring }\end{array}$ & $\begin{array}{l}? \\
? \\
?\end{array}$ & Habič 1989 \\
\hline
\end{tabular}

Tab. 1: Results of previous tracer tests. 
Environmental tracers were observed also. It was proved by chemical and isotopic analyses that besides autogenous recharge also the inflow from the alluvium of Soča river has an important contribution to the waters which are pumped for the drinking water supply at the Klariči pumping station (Urbanc \& Kristan 1998, Doctor et al. 2006).

\section{CHARACTERISTICS OF THE SEŽANA LANDFILL}

The landfill near Sežana (Fig. 3) is situated on karst terrain at the lithological contact between Upper Cretaceous limestone and dolomite. Carbonate rocks are tectonically

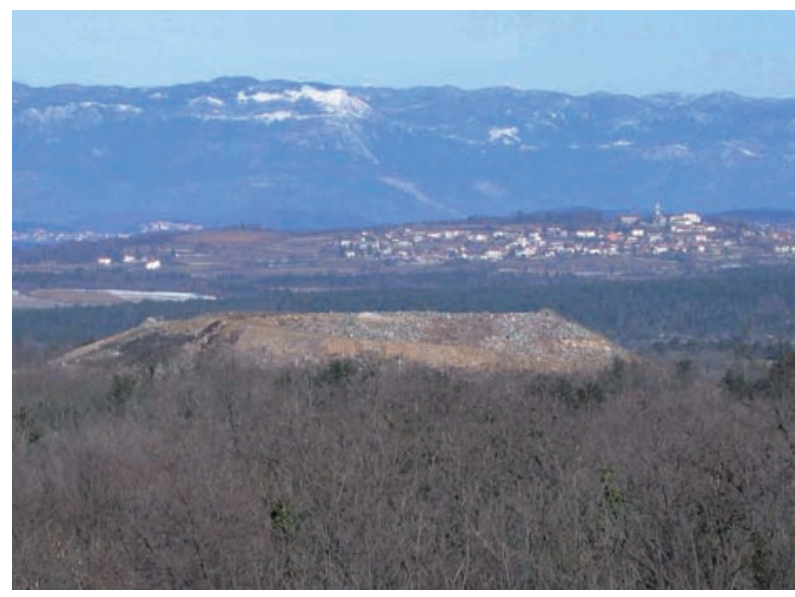

Fig. 3: The Sežana landfill (Photo: N. Ravbar).

Sl. 3: Odlagališče Sežana (Foto: N. Ravbar)

crushed in several directions (mainly E-W, NW-SE and NE-SW). Detailed tectonic-lithological mapping in the scale 1:2.500 showed that in the landfill area broken and fissured zones prevail, which are favourable for the vertical flow of water (Kogovšek et al. 1996). Rocks are covered with thin, often interrupted layers of soil with small protection function. The result of described characteristics is fast infiltration of water and substances dissolved in it from the surface into the underground. Based on the comparison of available data on water table in the caves of Kras the thickness of the vadose zone below the landfill was estimated to range between 185 and $225 \mathrm{~m}$ at different hydrological conditions.

In spring 1996 the leachates from the Sežana landfill were analysed in more details (Kogovšek 1996). Although the landfill is situated on karst terrain, the deposition of fine organic mud at the lower margin enabled accumulation of a small amount of leachates. A pipe was installed there through which accumulated water is drained. The first sample was taken at the pipe on 14 March 1996 at the end of a dry period of three weeks without precipitation, when existing snow cover was finally melted. The second sample was taken on 4 April 1996 after intensive rain (125 $\mathrm{mm}$ three days before) when fresh water was flowing through the pipe, and the third one at the end of April 1996 following a period of three weeks with only scarce precipitation. The first and the third samples were "old" leachates, accumulated for longer time on the surface and exposed to the processes of degradation and oxidation. In these samples high values of specific electrical conductivity (SEC up to $9000 \mu \mathrm{S} / \mathrm{cm}$ ), chlorides (up to $800 \mathrm{mg} / \mathrm{l}$ ), o-phosphates (up to $5 \mathrm{mg} / \mathrm{l}$ ) and nitrates (up to $19 \mathrm{mg} / \mathrm{l})$ were measured. The chemical oxygen demand (COD) was up to $900 \mathrm{mgO}_{2} / 1$ and the biochemical oxygen demand $\left(\mathrm{BOD}_{5}\right)$ up to $80 \mathrm{mgO}_{2} / \mathrm{l}$. In fresh leachate of the second sample lower values of SEC, chlorides, o-phosphates and nitrates, and higher values of COD (more than $2000 \mathrm{mgO}_{2} / \mathrm{l}$ ) and $\mathrm{BOD}_{5}$ were measured.

Less intensive precipitation, which is infiltrated only into the wastes, enables partial degradation of easy degradable organic pollution. But more intensive precipitation can push it deeper into the karstified rock, into the vadose zone of karst aquifer, which is an important milieu for further degradation also. At the conditions of high waters after intensive rains the pollution can reach the main groundwater flow through the channels of phreatic zone and flows towards the karst springs, in the example of the Sežana landfill mainly towards the Timava springs. Based on previous researches of the vadose zone above the Pivka Cave near Postojna (Kogovšek 1987) it was concluded that during the percolation through fissured karst rocks of the vadose zone the processes of self-purification are limited to a certain degree, which depends on the conditions in karst aquifer, characteristics of flow and types of contaminants.

Waste waters from the Sežana landfill were in 1996 polluted mostly with organic pollution (COD values more than $2000 \mathrm{mgO}_{2} / \mathrm{l}$ ) of which approximately one third is biologically degradable. The products of degradation (chlorides, nitrates, sulphates, phosphates, carbon dioxide, and others) are important factors in the process of karstificaton, which increases the permeability of flow paths from the surface deeper into the karst aquifer. This results in faster flow and lower self-purification. And in such conditions not only soluble components are washed out of the wastes with precipitation, but small, non-soluble organic pollutants can be transported also (Kogovšek 1996). 


\section{TRACER TEST IN APRIL 2005}

\section{PRECIPITATION AND HYDROLOGICAL CONDITIONS IN THE TIME OF TRACING}

The Environmental Agency of the Republic of Slovenia operates with the precipitation station near the water reservoir Sela na Krasu. We obtained data on daily precipitation for the period from 1 March 2005 to 17 January 2006. Additionally, at the Sežana landfill we installed a raingauge Onset RG2-M to measure precipitation in 15minutes intervals in the period from 21 April 2005 to 23 March 2006 (Fig. 6). Some differences between the two stations were observed, and to demonstrate the conditions in the whole Kras area the data from both locations were considered. The initial transfer of tracer through the vadose zone was initiated by the precipitation in the area of the landfill.

Common discharges of the Timava springs are regularly measured by the water supply company ACEGAS, which is responsible for the management of the springs. We obtained from them daily data on discharges for the years 2005 and 2006 (Fig. 6). For comparison discharges of the Reka river are presented on the Figure 6 also. They are regularly measured at the automatic gauging station Cerkvenikov mlin and data are available on the web page of the Environmental Agency (Podatki 2005).

After the period of low waters in the first part of the year 2005 the discharges of Timava increased after intensive rains in April, but no extreme values were measured. During the summer discharges remain relatively low in spite of frequent raining, and also in September and October no significant increases of discharge were observed. Only after intensive rain at the end of November 2005 the discharges increased over $100 \mathrm{~m}^{3} / \mathrm{s}$.

\section{INJECTION AND SAMPLING}

A karren surface at the south-western margin of the landfill was selected as the injection point. A solution of $38 \mathrm{~kg}$ of uranine in $400 \mathrm{l}$ of water was injected into a karst fissure on 20 April 2005 at 1:10 p.m. and washed off with $12 \mathrm{~m}^{3}$ of water (Fig. 4).

The sampling points (Fig. 1) and the sampling plan were chosen based on known hydrogeological conditions and results of previous tracer tests. In the period from the start of the test till the middle of January 2006 samples were taken once per day at the Timava 2 (more than 270 samples), Sardoč (200 samples) and Brojnica springs (more than 260 samples), and once or twice per day at the Klariči pumping station. At first two the water samples were collected manually in dark glass bottles by the co-workers of the ACEGAS company.

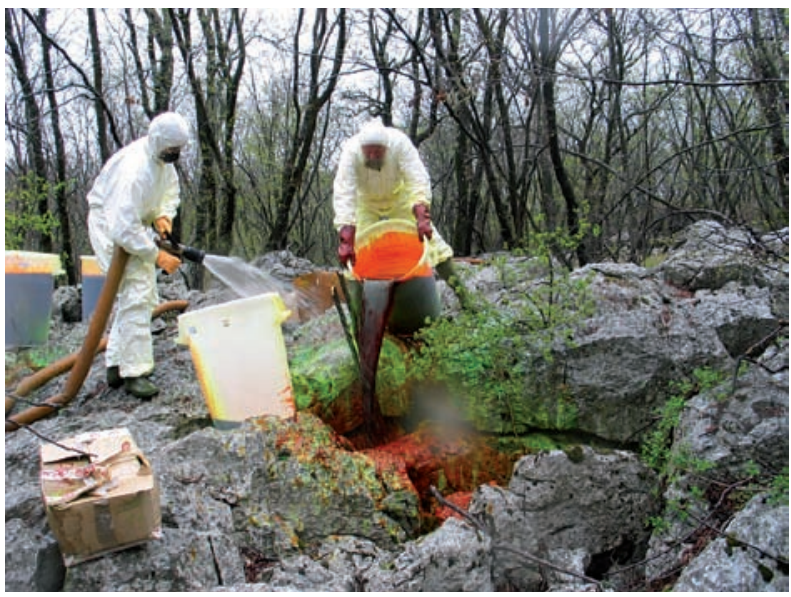

Fig. 4: Injection of tracer on 20 April 2005 at the margin of the Sežana landfill.

Sl. 4: Injiciranje sledila 20. aprila 2005 pri odlagališču Sežana.

More than one month they sampled the Moščenice-N spring also. At the Brojnica spring an automatic sampler ISCO 6700-A was installed (Fig. 5). At Klariči the samples were taken by the co-workers of the water supply

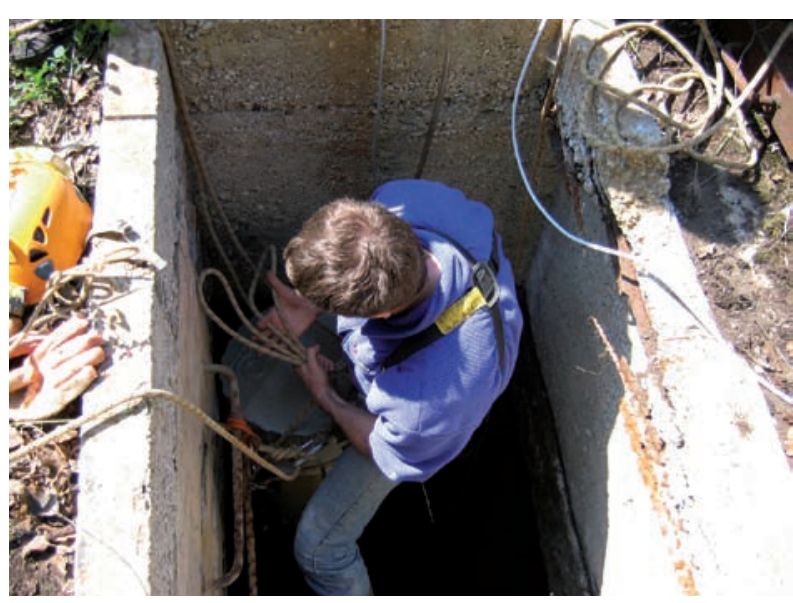

Fig. 5: Installation of the automatic sampler at the Brojnica spring.

Sl. 5: Postavitev avtomatskega zajemalnika v izvir Brojnico.

company Kraški vodovod (near 300 samples), but fluorescence was measured (in hourly intervals) in situ by Fiber-optic Fluorometer LLF-M also. In the time of low and medium waters numerous blind samples (around 250 up to December 2005) were taken at Klariči. Within this period no intensive rainfall events were observed, and this is the reason why no blind samples were taken at high waters. 
Additionally, 5 series of samples were taken simultaneously in all three branches of the Timava spring to compare uranine concentrations, but no significant differences in the appearance of tracer were observed. So the concentrations measured in Timava 2 were regarded as representative for the Timava springs.

Fluorescence was measured in laboratory by a Luminescence spectrometer LS 30, Perkin Elmer $\left(\mathrm{E}_{\mathrm{ex}}=491\right.$ $\mathrm{nm}, \mathrm{E}_{\mathrm{em}}=512 \mathrm{~nm}$ ) with detection limit of $0.005 \mathrm{ppb}$ (1 $\left.\mathrm{ppb}=1 \mathrm{mg} / \mathrm{m}^{3}\right)$. First measurements were carried out immediately after sampling and then also later when possible suspended particles in the samples were decanted. Low, uncertain concentrations were additionally checked several times with simultaneous testing and adjusting of $\mathrm{pH}$.

\section{RESULTS OF TRACING}

In daily samples of the Timava 2 spring first traces of uranine $(0.015 \mathrm{ppb})$ were detected on 2 May 2005 at 8 a.m. (Figs. 6 and 8). For the appearance of tracer the rain $(20 \mathrm{~mm})$ on 24 and 25 April 2005 was decisive. Then

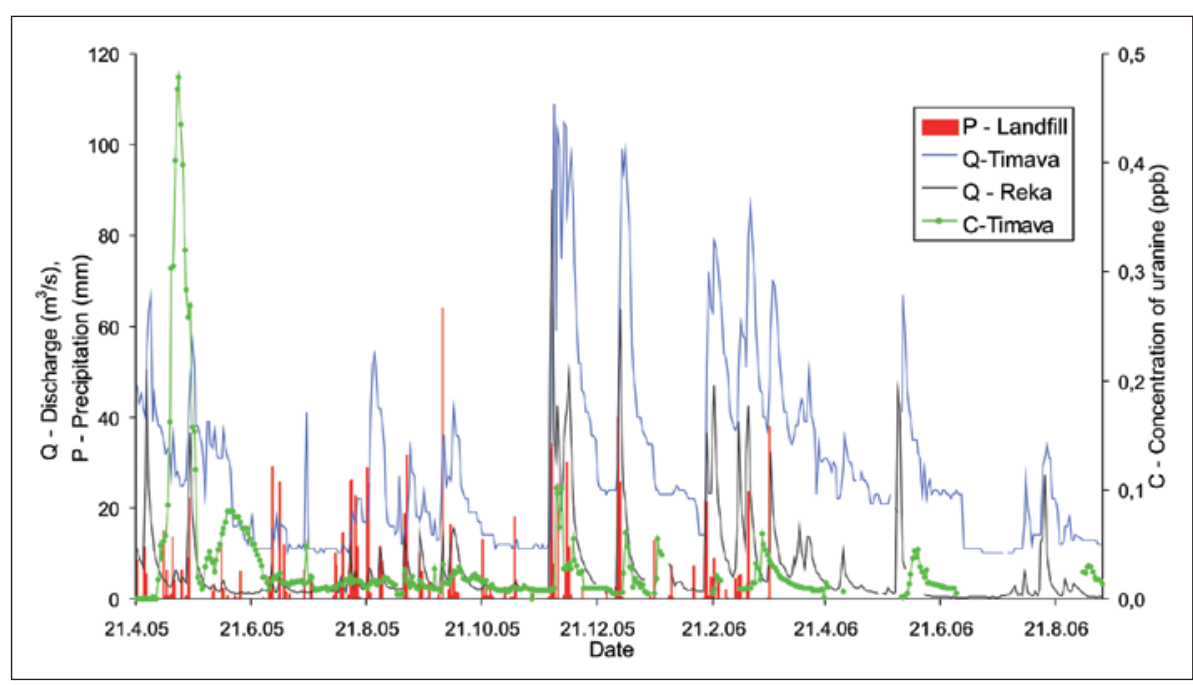

Fig. 6: Concentrations of uranine in the Timava spring, discharges of the Timava springs and Reka river, and precipitation at the Sežana landfill (precipitation measured until 23 March 2006).

Sl. 6: Koncentracije uranina v izviru Timave, pretoki Timave in Reke ter padavine na območju odlagališča Sežana (padavine merjene do 23. marca 2006).

Tab. 2: Estimation of the apparent velocities of groundwater flow.

\begin{tabular}{|l|l|l|l|l|l|l|l|}
\hline Spring & $\begin{array}{l}D \\
(\mathrm{~m})\end{array}$ & $\begin{array}{l}C_{\max } \\
(\mathrm{ppb})\end{array}$ & $\begin{array}{l}\boldsymbol{t}_{\max } \\
(\text { days })\end{array}$ & $\begin{array}{l}\boldsymbol{v}_{\max } \\
(\mathrm{m} / \mathrm{h})\end{array}$ & $\begin{array}{l}\boldsymbol{t}_{\text {dom }} \\
(\text { days })\end{array}$ & $\begin{array}{l}\boldsymbol{v}_{\text {dom }} \\
(\mathrm{m} / \mathrm{h})\end{array}$ & $\begin{array}{l}\text { Recovery } \\
(\%)\end{array}$ \\
\hline Timava & 21350 & 0.48 & 12 & 76 & 23 & 39 & 93 \\
\hline Brojnica & 14155 & 0.14 & 30 & 20 & 31 & 19 & \\
\hline Sardoč & 21655 & 0.02 & & & & & \\
\hline Klariči & 21980 & 0.01 & & & & & \\
\hline
\end{tabular}




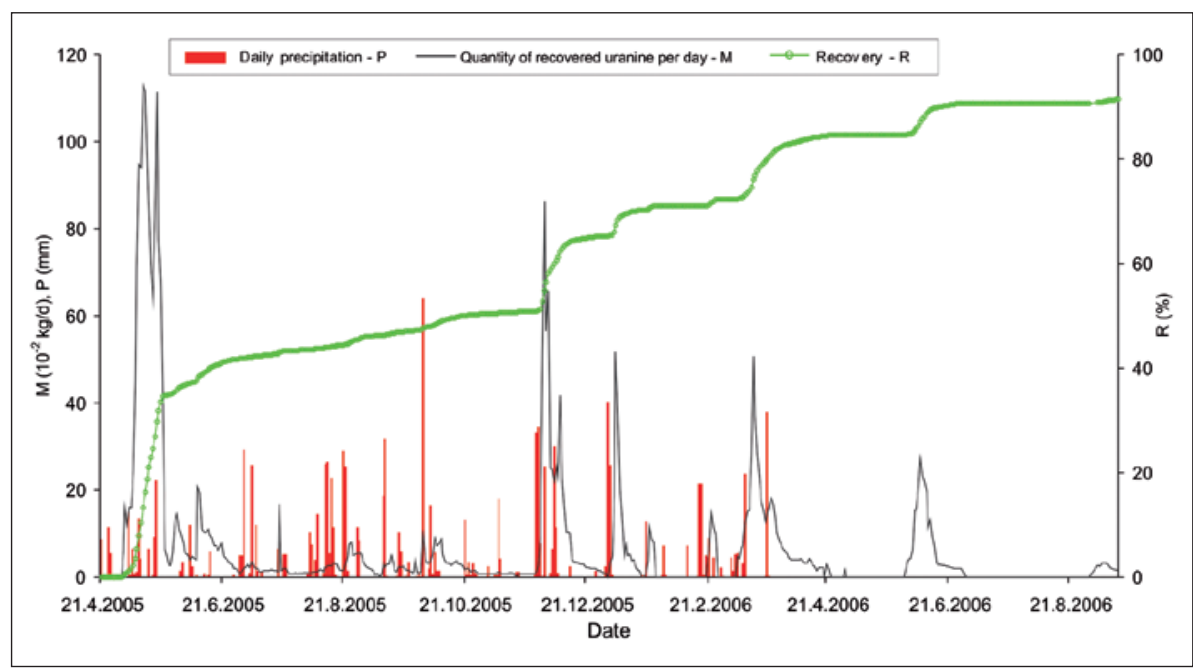

Fig. 7: Comparison between precipitation and recovered amount of tracer in the Timava spring (precipitation measured until 23 March 2006).

Sl. 7: Primerjava med padavinami in količino povrnjenega sledila skozi izvir Timave (padavine merjene do 23. marca 2006).

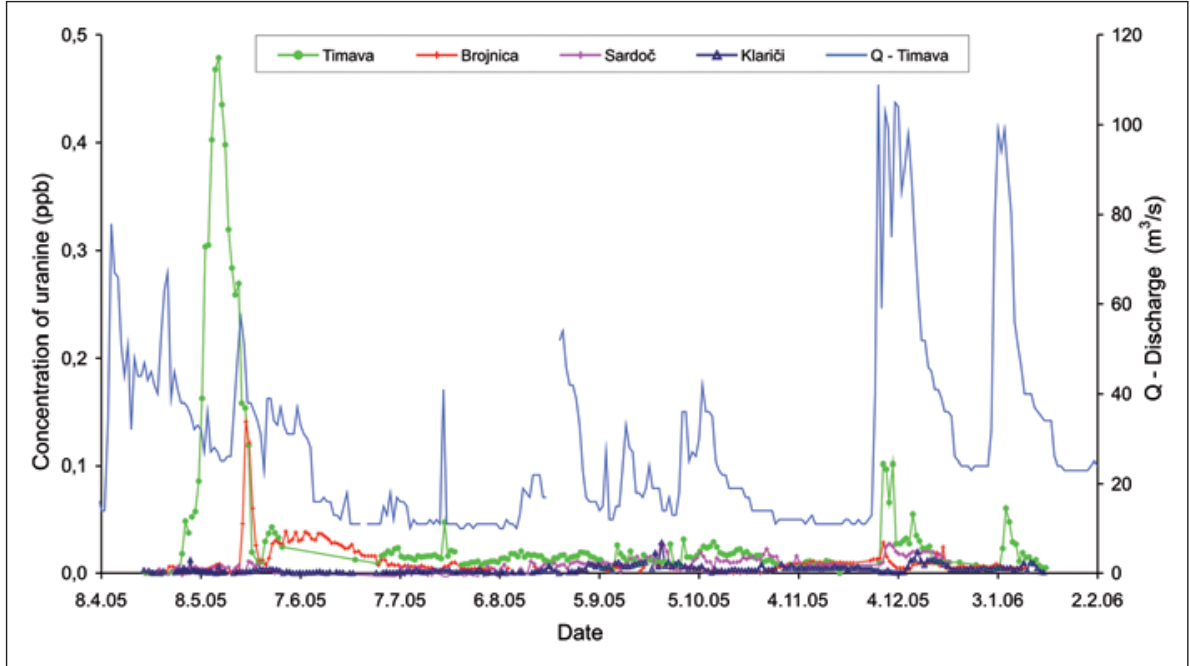

Fig. 8: Concentrations of uranine in the Timava, Sardoč and Brojnica springs and Klariči pumping station, and discharges of the Timava springs.

Sl. 8: Primerjava krivulj koncentracije sledila v izvirih Timava, Sardoč in Brojnica ter v črpališču Klariči po injiciranju uranina 20. aprila 2005 na območju odlagališča Sežana in narejeni pretoki izvirov Timave.

small amount of injected tracer is still stored in the karst aquifer.

Based on the comparison between measured uranine concentrations and discharges of Timava the amount of recovered tracer was calculated (Fig. 7). In the period from the injection of tracer in April 2005 until the end of September 2006 (17 months in total) almost 35 $\mathrm{kg}$ of uranine (93\% of injected amount) was washed out through the Timava springs. This share is probably even higher considering the fact that in a short interval during the summer 2006 no samples were taken (Fig. 6).

Until 19 May 2005 only small oscillations of uranine concentrations slightly above the detection limit were measured in daily samples of the Brojnica spring. Then on 20 May, one month after the injection, the concentration increased and a nice breakthrough curve was observed. Its shape was similar to the one of the Timava spring, only the peak concentration with $0.14 \mathrm{ppb}$ on 21 May 2005 was significantly lower (Fig. 8). The concentration decreased to $0.005 \mathrm{ppb}$ on 26 May 2005. But during the next day, similar to the conditions observed at the Timava spring, it started to increase again and the second breakthrough peak with the maximum value in the beginning of June 2005 was formed. Slightly increased concentrations were detected again during high waters in the autumn of 2005. Calculated maximal apparent velocity of flow towards the Brojnica spring was $20 \mathrm{~m} / \mathrm{h}$ and dominant apparent flow velocity $19 \mathrm{~m} / \mathrm{h}$. No data on discharges of the Brojnica spring are available therefore the calculation of recovered amount of tracer was not possible. But according to our field observations these discharges were significantly smaller than the discharges of Timava springs. Also measured concentrations of uranine were low, so it can be assessed that the outflow through the Brojnica spring was less than $1 \%$ of injected tracer.

Oscillations of tracer concentrations around the detection limit were observed by regular daily sampling at the Sardoč spring in the period of one month after the injection. Then on 22 May 2005 the concentration increased to $0.010 \mathrm{ppb}$. In the following days concentra- 
tions were decreasing and after 5 days the detection limit was reached again (Fig. 8). During high waters in autumn 2005 concentrations of uranine increased up to a maximum level of $0.02 \mathrm{ppb}$. Although the tracer appearance in the Sardoč spring was weak, a secondary underground water connection with the landfill can be confirmed considering the shape of the breakthrough curve and its similarity with the curves of other observed springs. But in comparison with the Timava spring the amount of recovered tracer at the Sardoč spring was very low.

In the Klariči pumping station the concentrations of tracer were measured with field fluorometer, but also water samples for the laboratory analysis with the luminiscence spectrometer were taken once or twice per day in the water reservoir Sela na Krasu. Measured values were in general below the detection limit (Fig. 8). In the spring 2005 four individual (in single samples) increases of the concentration of uranine to $0.010 \mathrm{ppb}$ were observed, but such individual peaks are not sufficient to confirm the underground water connection. Following slightly more intensive precipitation in the second half of September 2005 the concentrations were higher again in two samples. Similar short-term oscillations were observed in other springs and we infer that they were only a reflection of a natural outflow of pollution from the karst aquifer after a dry summer period.

After intensive precipitation at the end of November and in the beginning of December 2005 the karst aqui- fer was filled with water. At the Klariči pumping station the tracer concentration increased to $0.015 \mathrm{ppb}$. These values were only slightly above the detection limit, but they were measured in several successive samples. In the studied karst area between the landfill and the springs in the Trieste bay a water flow through the main conduits is dominant, but in the conditions of a significant rise of water table groundwater can spill over in a broader area with lower permeability. From the obtained results we can infer that at extreme hydrological conditions and flowing slowly through smaller fissures only a slight amount of injected tracer reached the Klariči pumping station in a short water wave. Calculated amount of recovered tracer at Klariči (considering the quantity of pumping $140 \mathrm{l} / \mathrm{s}$ ) is very low (approximately $1 \mathrm{~g}$ of uranine). This would mean that only $0.003 \%$ of the injected quantity was detected at the Klariči pumping station. On the other hand, we can not exclude the possibility that measured increased concentrations were the result of a natural outflow of pollution from the catchment. To accept or reject this hypothesis we would need to analyse some blind samples taken at similar hydrological conditions of high waters. In the frame of the described research such analysis was not possible, but after a certain period in the future (when all injected tracer will be washed out) we could get the necessary information by the analysis of series of samples taken in adequate hydrological conditions of very high waters.

\section{CONCLUSIONS}

Infiltrated precipitation and leachates from the Sežana landfill flow underground through the karst aquifer towards the Timava springs (Fig. 1). The first appearance of uranine (12 days after the injection) was initiated by the rain event $(20 \mathrm{~mm}) 5$ days after the injection $(25$ and 26 April 2005). In the following days until 23 May 2005 the most significant part of the breakthrough curve was observed with the outflow of $35 \%$ of injected tracer (Figs. 6 and 7). It was caused by precipitation in the time from 5 to 11 May $2005(42 \mathrm{~mm}$ ) and later from 17 to 18 May $2005(32 \mathrm{~mm})$. The highest concentration of uranine $(0.48 \mathrm{ppb})$ was measured 23 days after the injection on 13 May 2005. The discharges of Timava springs and Reka river were in recession until 17 May, so no faster transport through the karst channels towards the springs was generated (Fig. 6). Only the increase of discharge of Timava in the period from 18 to 20 May 2005 from 26 to 57 $\mathrm{m}^{3} / \mathrm{s}$ and the increase of discharge of Reka from 1 to 3.4 $\mathrm{m}^{3} / \mathrm{s}$ caused important transport of tracer.
A comparison with the observations of water percolation and transport of tracer through one hundred meters thick vadose zone above the Postojna Cave (Kogovšek 2007) in the same period indicates that the structure of the vadose zone below the landfill enables relatively fast water flow. Precipitation events at the end of April and in the beginning of May 2005 pushed the tracer through the vadose zone towards the phreatic zone only through highly permeable flow paths (similar to the trickle I, which was proved in a long-term study of the vadose zone in the Postojna Cave as the most permeable of the three observed trickles). In the less permeable parts of the vadose zone the tracer was temporary stored. Such storage of infiltrated precipitation was dominant also in the following period until the middle of August 2005, therefore in the meantime only traces of uranine were detected at the Timava springs. We can infer that during this summer the Timava springs were mainly recharged from other parts of the aquifer (Timeus 1928, Bidovec 1967, 
Doctor et al. 2006). The total amount of precipitation in the period of 5 months after injection from July to the end of November 2005 was almost $600 \mathrm{~mm}$ (measured at the landfill), but due to a high evapotranspiration and the storage within the vadose zone the transfer of tracer through it was relatively low (10\%). Higher concentrations of tracer at the Timava springs were observed again at the end of November 2005 when more intensive and larger precipitation started, as well as in spring 2006.

We can conclude that the transport through the vadose zone has a decisive influence on the transfer of tracer or by analogy of contaminants from surface towards karst springs. It depends not only on the quantity and intensity of precipitation, but on the amount of water previously stored in the vadose zone also.

Apparent dominant flow velocity in the conditions of low discharges of Timava (around $30 \mathrm{~m}^{3} / \mathrm{s}$ ) was approximately $39 \mathrm{~m} / \mathrm{h}$ (Tab. 2). Almost $42 \%$ of injected tracer was recovered through the Timava springs in the first two months after the injection, and approximately 93\% in the period of 16 months until September 2006 (Fig. 7). Probably smaller amounts of tracer were washed out following each more intensive precipitation event in the period after the end of the described research also.

The underground water connection with the Brojnica spring was proved also. The maximal measured concentration of tracer was $0.14 \mathrm{ppb}$, which is 3.5-times lower than in the Timava spring. The first appearance of tracer was observed only 31 days after the injection following the increase of discharges after a precipitation event. The apparent dominant flow velocity was $19 \mathrm{~m} / \mathrm{h}$ (Tab. 2). Even lower concentrations were measured in the Sardoč spring 33 days after the injection.

In the Klariči pumping station the concentrations of uranine were in the initial period of 5 months constantly below the detection limit. Only in some individual samples in September 2005 slightly higher concentrations were detected. They were probably caused by a natural outflow of pollution from the karst aquifer after a dry summer period. At the end of the period of very high waters in the beginning of December 2005 the concentrations of uranine reached up to $0.015 \mathrm{ppb}$ in sev- eral samples (at the same time a breakthrough curve was observed at the Timava springs also). These increased values could be a result of a natural outflow of pollution from the catchment again, but it is possible also that in the conditions of very high waters groundwater can spill over from the primary drainage path into a broader area with lower permeability. At extreme hydrological conditions and flowing slowly through smaller fissures only a slight amount of tracer (some permiles) reached the Klariči pumping station in a short water wave. We can say that no permanent underground water connection between the landfill and the Klariči pumping station exists and that such connection could be activated only at some exceptional events and in short time periods.

It was proved by tracer test that infiltrated water from the Sežana landfill flows towards the Timava and Brojnica springs. Therefore both springs are suggested as the points of monitoring of groundwater quality in the area of influence of the landfill. Although a possible influence of the landfill on the Klariči pumping station is very low, also this location was selected as the monitoring point due to its exceptional importance for the water supply in the Kras region.

Based on described results and our previous experiences some guidelines for the monitoring can be emphasised. The monitoring plan should be adjusted to hydrological conditions, because the pollution signal can be expected at monitoring points after each more intensive precipitation event due to a more intensive washing out of contaminants from the landfill. Additionally, previously stored polluted water from the vadose zone below the landfill is pushed towards the phreatic zone, in which then the transport towards the karst springs is very fast. As the conditions in karst are changing very fast the frequency of sampling should be adapted to hydrological conditions. More detailed sampling during a selected water wave from the beginning of the increase of discharge, through the discharge peak and then in the recession phase back to the initial state is suggested in order to get more representative results. Observation of selected water waves in spring and autumn is proposed.

\section{ACKNOWLEDGEMENT}

We would like to thank Prof. Dr. Franco Cucchi and his research team from the Department of Geological, Environmental and Marine Sciences, University of Trieste for their help in the organisation of the tracer test. For the organisation of sampling at the springs of Timava, Sardoč and Moščenice-N, and for discharge data we would like to thank the water supply company ACEGAS from Trieste and especially Mr. Paolo Sossi for his special care and interest. For the organisation of sampling at the Klariči pumping station we would like to thank the co-workers 
of the water supply company Kraški vodovod Sežana. For co-operation in the preparative arrangements we would like to thank Andrej Juren (GeoSi d.o.o., Geological Institute). The tracer test was supported by the Institute of
Mining, Geology and Geotechnology from Ljubljana, and by the public company Komunalno stanovanjsko podjetje Sežana, which is the manager of the landfill.

\section{REFERENCES}

Bidovec, F., 1967: The Hydrosystem of Karstic Springs in the Timavo Basin.- Hydrology of Fractured Rocks, 1, 263-274, AIHS, Louvain.

Civita, M. \& F. Cucchi \& S. Garavoglia \& F. Maranzana \& B. Vigna, 1995: The Timavo hydrogeologic system: an important reservoir of supplementary water resources to be reclaimed and protected.- Acta carsologica, 24, 169-186, Ljubljana.

Cucchi, F. \& L. Zini, 2002: Underground Timavo river monitoring.- Acta carsologica, 31, 75-84, Ljubljana.

Doctor, D.H. \& E.C. Alexander \& M. Petrič \& J. Kogovšek \& J. Urbanc \& S. Lojen \& W. Stichler, 2006: Quantification of Karst aquifer discharge components during storm events through end-member mixing analysis using natural chemistry and stable isotopes as tracers.- Hydrogeological journal, 14, 1171-1191, Berlin Heidelberg.

Gabrovšek, F. \& B. Peric, 2006: Monitoring the flood pulses in the epiphreatic zone of karst aquifers: The case of Reka river system, Karst plateau, SW Slovenia.- Acta carsologica, 35/1, 35-45, Ljubljana.

Habič, P., 1989: Kraška bifurkacija Pivke na jadransko črnomorskem razvodju.- Acta carsologica, 18, 233264, Ljubljana.

Kogovšek, J., 1987: Naravno čiščenje sanitarnih odplak pri vertikalnem prenikanju v Pivki jami.- Acta carsologica, 16,123-139, Ljubljana.

Kogovšek, J. 1996: Kako smetišča ogrožajo kakovost kraške vode.- Annales, 9, 111-114, Koper.

Kogovšek, J., 2007: Ugotavljanje dinamike pretakanja padavin skozi vadozno cono krasa na osnovi meritev pretoka.- Acta carsologica, 36/2, 245-254, Ljubljana.

Kogovšek, J. \& M. Knez \& M. Petrič \& T. Slabe \& S. Šebela, 1996: Geološke raziskave o vplivu izcednih voda iz odlagališča komunalnih odpadkov Sežana.- Tipkano poročilo, IZRK ZRC SAZU, 16 str., Postojna.
Kogovšek, J. \& M. Petrič, 2006: Tracer test on the Mala gora landfill near Ribnica in south-eastern Slovenia.- Acta carsologica, 35/2, 91-101, Ljubljana.

Kolbezen, M. \& J. Pristov, 1998: Površinski vodotoki in vodna bilanca Slovenije.- MOP-Hidrometeorološki zavod Republike Slovenije, p. 98, Ljubljana.

Komunalno stanovanjsko podjetje, 2005: http://www. ksp-sezana.si

Kranjc, A. (Ed.) 1997: Slovene Classical Karst - Kras.ZRC Publishing, 321 pp, Ljubljana.

Mosetti, F., 1965: Nuova interpretacione di un esperimento di marcatura radioattiva del Timavo.- Bolletino di Geofisica teorica et applicata, 7, 27, 218-243, Udine.

Podatki, 2005: Podatki avtomatskih merilnih postaj (quoted April 2005-September 2006).- http://www. arso.gov.si/vode/podatki/amp/amp.html

Reisenhofer, E. \& G. Adami \& P. Barbieri, 1998: Using chemical and physical parameters to define the quality of karstic freshwaters (Timavo river, northeastern Italy): a chemometric approach.- Wat. Res., 32/4, 1193-1203, London.

Timeus, G., 1928: Nei misteri del mondo sotterraneo. Risultati delle ricerche idrologiche sul Timavo 18951914, 1918-1927.- Alpi Giulie, 29, 1, 2-40, Trieste.

Trček, B., 2006: How can the epikarst zone influence the karst aquifer hydraulic behaviour?- Environmental Geology, 51, 761-765, Berlin.

Urbanc, J. \& S. Kristan, 1998: Isotope investigation of the Brestovica water source during an intensive pumping test.- RMZ-Materials and Geoenvironment, 45, 1/2, 187-191, Ljubljana. 


\title{
SMERI IN DINAMIKA ODTEKANJA VODE IN PRENOSA KONTAMINANTOV Z ODLAGALIŠČA ODPADKOV PRI SEŽANI (JZ SLOVENIJA)
}

\author{
POVZETEK
}

$\mathrm{V}$ raziskavi s sledilnim poskusom na odlagališču komunalnih odpadkov pri Sežani smo iskali odgovor na naslednja vprašanja: v kateri smeri in kako hitro se v podzemlju pretaka infiltrirana voda $z$ območja odlagališča, kako hiter je transport škodljivih snovi, ki jih je ta voda sprala iz odloženih odpadkov in $\mathrm{v}$ katerih izvirih ali jamah $\mathrm{z}$ vodnim tokom lahko pričakujemo pojav teh snovi. Vzporedno merjenje padavin, pretokov in koncentracij sledila $\mathrm{v}$ daljšem obdobju je omogočilo določitev vpliva različno izdatnih in intenzivnih padavin na pojavljanje sledila $\mathrm{v}$ izvirih in s tem oceno vpliva vadozne cone na podzemno pretakanje infiltrirane vode.

Območje odlagališča (Sl. 3) je del Krasa, ki ga gradijo pretežno zakraseli in dobro prepustni kredni apnenci in deloma dolomiti in je praktično brez površinskih tokov (Sl. 1). Napaja se primarno z infiltracijo padavin in sekundarno s ponikalnicami z nekraškega obrobja, prazni pa skozi kraške izvire v Tržaškem zalivu. Največji med njimi so izviri Timave s srednjim pretokom $30,2 \mathrm{~m}^{3} / \mathrm{s}$ (S1. 2), v njihovi neposredni bližini je izvir Sardoč, zelo zanimiv pa je podmorski izvir Brojnica pri Nabrežini (Sl. 5). Ob morju ali globlje v notranjosti celine so še številni drugi izviri. $\mathrm{V}$ črpališču Klariči pa zajemajo podzemno vodo za vodookrbo petih občin na območju Krasa.

$\mathrm{Na}$ Krasu so bili $\mathrm{v}$ preteklosti izvedeni številni sledilni poskusi, s katerimi je bila dokazana primarna smer pretakanja proti izvirom Timave (Sl. 1). Ugotovljene so bile visoke navidezne hitrosti pretakanja, ki so značilne za tok skozi kraške kanale in kažejo na dobro in hitro komunikacijo vode v obravnavanem vodonosniku. $\mathrm{V}$ vseh poskusih pa je bilo sledilo injicirano v ponikalnico ali vodni tok v podzemni jami. Da bi ugotovili način odtekanja izcednih vod s sežanske deponije, je bil zasnovan nov sledilni poskus $\mathrm{z}$ injiciranjem sledila $\mathrm{v}$ sistem škrapelj na robu odlagališča. V razpoko smo 20. aprila 2005 injicirali raztopino $38 \mathrm{~kg}$ uranina (Sl. 4).

Rezultati sledenja so prikazani na slikah 1, 6, 7 in 8 . Navidezna dominantna hitrost pretakanja proti izvirom Timave znaša $39 \mathrm{~m} / \mathrm{h}$. Skozi izvire Timave je v prvih dveh mesecih izteklo skoraj $42 \%$ injicirane količine, medtem ko je do septembra 2006 (v obdobju 16 mesecev) izteklo okoli 93 \% sledila. Padavine konec aprila in maja so potisnile sledilo do podzemnega toka Reke le po prepustnejših poteh, v slabše prepustnih delih vadozne cone pa so se padavine s sledilom tedaj le shranjevale. Nadaljnje padavine do srede avgusta so se pretežno shranjevale, kar pojasnjuje neizrazito pojavljanje sledila ob nihanjih pretoka Timave. Očitno so izviri Timave tedaj dobivali vodo pretežno iz drugih delov vodonosnika. V skoraj 5 mesečnem obdobju od julija do konca novembra 2005 je padlo na območju odlagališča skoraj $600 \mathrm{~mm}$ dežja, a je bil prenos sledila skozi vadozno cono sorazmerno majhen (10\%). Do ponovnega izrazitejšega prenosa sledila skozi izvire Timave je prišlo šele konec novembra 2005. Rezultati so pokazali, da je za prenos sledila oz. topnih kontaminantov s površja do kraških izvirov odločilen prenos skozi vadozno cono, ki pa je odvisen ne le od količine in intenzivnosti padavin, temveč predvsem od predhodne zapolnjenosti vadozne cone $z$ vodo.

Sledilni poskus je dokazal tudi povezavo odlagališča z Brojnico pri Nabrežini. Uranin se je pojavil šele $31 \mathrm{dni}$ po injiciranju, ko so se vodostaji voda po padavinah zvišali. Izračunana dominantna hitrost pretakanja $\mathrm{v}$ tej smeri je bila $19 \mathrm{~m} / \mathrm{h}$. Še manj izrazito se je sledilo pojavilo v izviru Sardoč 33 dni po injiciranju.

$\mathrm{V}$ črpališču Klariči so bile koncentracije večinoma pod mejo detekcije, zabeležili smo le nekaj neznačilnih povišanj. V začetku decembra 2005 ob koncu obdobja zelo visokega vodostaja, ko je prišlo do ponovnega prenosa sledila skozi izvire Timave, pa je več zaporednih vzorcev dosegalo koncentracije do 0,015 ppb. Sklepamo, da ne gre za stalno odtekanje iz smeri odlagališča proti črpališču Klariči, ampak bolj za izjemne in časovno omejene dogodke, ko se lahko ob zelo visokih vodostajih podzemna voda iz območja primarnih drenažnih poti, ki so usmerjene proti izvirom Timave, precedi tudi $\mathrm{v}$ širše območje proti severu in njen zelo majhen del (nekaj tisočink odstotka) in $\mathrm{z}$ večjo zakasnitvijo doseže tudi črpališče v Klaričih. Po drugi strani pa ne moremo izključiti niti možnosti, da so povišane koncentracije posledica naravnega iztoka onesnaženja iz kraškega vodonosnika. Da bi lahko potrdili ali zavrgli to zadnjo hipotezo, bi morali analizirati serijo slepih vzorcev, ki bi bili odvzeti v podobnih hidroloških pogojih zelo visokih vod. Žal v okviru opisane raziskave taka analiza ni bila možna, lahko pa bi jo izvedli naknadno, ko bi injicirano sledilo v celoti izteklo iz sistema. 